\title{
Investigation of Empathy as a Moderator of the Relationship Between Social Identity and Helping Behavior in Young Adults
}

\author{
Elvan KİREMITÇİ CANIOZ1 ${ }^{1}$, Hamit COŞKUN²
}

\begin{abstract}
In this study, the effect of social identity on helping behavior and the moderator role of empathy on this effect were examined. Participants were university students who study in Bolu Abant Izzet Baysal University. Social identity was manipulated by providing information about university student who was a Turkish, Syrian or Greek student. Participant's empathy levels were measured by Basic Empathy Scale (BES). And also, helping behavior measured by the Help Text which was improved by researchers. In expressions were given to participants about a university student who needs help and then they were asked how much they would share with him if they had the amount the student needed. Findings indicated that helping behavior and empathy levels of participants were manipulated by social identity. Participants who are in Syrian student condition helped more and felt more empathy than other conditions. Also, we found that there is a moderator role of empathy on the effect of social identity on helping behavior. The results are consistent believing in same religion, social responsibility norms and Conservation of Resources Theory. There is suggested that new researchers can examine this research design in another identities and samples.
\end{abstract}

Key Words: Social İdentity, Empathy, Helping Behavior, Positive Psychology, Prosocial Behavior.

\section{Genç Yetişkinlerde Sosyal Kimlik ve Yardım Etme Davranışı Arasındaki İlişkide Empatinin Düzenleyici Rolünün İncelenmesi}

Özet: Bu çalışmanın amacı, sosyal kimliğin empati ve yardım etme davranışı üzerindeki etkisini incelemektir. $\mathrm{Bu}$ amaçla değişkenler incelendiğinde, sosyal kimliğin bireyin toplum içerisindeki kimliği olduğu bilinmektedir. Yardım etme davranışını en çok etkileyen değişkenlerden biri olan empati, bireyin bir başkasının yaşadığı duyguyu hissetmesi ve düşüncesini anlaması olarak ifade edilmektedir. Yardım etme davranışı ise, bireyin kendisini daha iyi hissetmesini sağlayan olumlu sosyal davranışlardan biridir. Bu çalışmada katılımcılar üniversite öğrencilerinden oluşmaktadır. Çalışmada araştırmacılar tarafından hazırlanan Türk, Suriyeli ve Yunan grup olmak üzere üç farklı sosyal kimlik manipülasyonu yapılmıştır. Katılımcılara, yardımlarına ihtiyacı olduğunu belirten ve beş farklı uzman görüşü alınarak hazırlanan, üç farklı üniversite öğrencisine ait metinler verilmiştir. Katılımcıların empati puanları, Temel Empati Ölçeği (TEÖ) yardımı ile ölçülmüştür. Yardım etme davranışı ise, araştırmacılar tarafından hazırlanan Yardım Metni ile ölçülmüş, manipülasyon sırasında bahsedilen öğrenciye yönelik ifadeler verilmiş ve ardından, bu öğrencinin ihtiyacı olan miktara sahip olsalar ne kadarını onunla paylaşacakları sorulmuştur. Bulgular incelendiğinde, sosyal kimliğe bağlı olarak katılımcıların empati puanlarının ve yardım etme davranışlarının yardım edilenin kimliğine göre anlamlı olarak farklılaştığı görülmüştür. Ayrıca, sosyal kimliğin yardım etme davranışı üzerindeki etkisinde empatinin düzenleyici rolü olduğu bulunmuştur.

Anahtar Kelimeler: Sosyal Kimlik, Empati, Yardım Etme Davranışı, Pozitif Psikoloji, Prososyal Davranış.

${ }^{1}$ Asst. Prof., Balikesir University, Department of Psychology, Orcid Id: https://orcid.org/ 0000-0003-4733-4780

${ }^{2}$ Prof., Bolu Abant Izzet Baysal University, Department of Psychology, Orcid Id: https://orcid.org/ 0000-0002-5509-8717.

Address of correspondence/Yazışma Adresi: Dr. Öğretim Üyesi Elvan Kiremitci Canioz. Balikesir University, Department of Psychology, Turkey. E.mail: kiremitci.elvan@gmail.com

Date of Received/Geliș Tarihi: 16.03.2020, Date of Revision/Düzeltme Tarihi: 11.05.2020, Date of Acceptance/Kabul Tarihi: 16.05 .2020

Citing/ Referans Gösterimi: Kiremitçi Canız, E. ve Çoşkun, H. (2020). Investigation of Empathy as a Moderator of the Relationship Between Social Identity and Helping Behavior in Young Adults. Kıbrıs Türk Psikiyatri ve Psikoloji Dergisi, 2(2): 75-81 doi:10.35365/ctjpp.20.02.11 


\section{Introduction}

Social identity is a type of identity that an individual has in society. The individual sees others in the same group as an in-group member and the individuals who are not in the same group as an out group member. As they belong to the same category, they perceive them more similar and attribute more positive emotions to the group, while their feeling are more negative and they show negative behaviors towards the out-group. Therefore, while showing helping behavior, it tends to in group bias (Tajfel \& Turner, 1979; Tajfel, 1982).

When helping behavior to out-group members is examined, we decide to help or not depending on such as amount, quality and empathy. Furthermore, the intention of this helping predicts whether we will demonstrate this behavior (Dovidio et. al., 1997; Johnston \& Glasford, 2017; Levine, Cassidy \& Brazier, 2002).

Two of the most important emotional factors that affect helping behavior are guilt and shame. Feeling guilty towards a group or a member increases individuals' helping behavior. For example, it is known that these two mechanisms are located under helping behaviors of individuals with white skin color, when helping behavior for who are exposed to discrimination such as black people is examined (Oswald \& Harvey, 2000).

If the individual identifies himself/herself with nationality at a high level, he/she helps less to out-group member (Zebel, Doosje \& Spears, 2009). In another study of social identity, it was found that the Dutch who identified themselves highly with their nationality were more proud of their nationality than Jews who were members of an external group and felt more collective guilt (van Leeuwen, van Dijk \& Kaynak, 2013). Also, Verkuyten and Reijerse (2008), in their study with Turkish minority groups who are living in the Netherlands, showed that when the participants saw their groups more permeable, they showed less Turkish identity and higher Dutch identity.

The fact that individuals who identify themselves with their nationalities at a high level has positive attitudes towards their in-group and they help more to their ingroup. Especially in large donations, it is seen that the relations between countries affect this charity as much as the relations between group members (James \& Zagefka, 2017).

\section{Empathy}

Empathy is generally defined as condition when the individual understands the emotions and thoughts of another and expresses this situation to that person. Therefore, empathy is the best condition of prosocial behaviors such as helping behavior (Atkins, Hart \& Donnelly, 2004; Welp \& Brown, 2014). Many studies have found that individuals help more people who feel empathically close to them (Paciello et. al., 2013; Richman, DeWall \& Wolff, 2015).

In the literature studies have indicated that empathy is not only predictive of helping behavior, but also shown the effect of some variables such as sense of responsibility on helping. People can feel that they have to help someone, whom they have responsibility for helping according to the norm of responsibility (Basil, Ridgway \& Basil,
2006). The other research has shown that empathy is one of the most important variable that affect helping behavior. Individual feels a responsibility for another person to help and feel more intention to helping behavior (Pavey, Greitemeyer \& Sparks, 2012).

\section{Helping Behavior}

One of the prosocial behaviors that strengthens interpersonal relationships is helping behavior, which is expressed as a voluntary behavior for needs of anothers (Jolliffe \& Farrington, 2006; Oarga, Stavrova \& Fetchenhauer, 2015).

The importance of empathy is being the best condition of helping behavior. The individuals tend to help more empathically to whom they approach according to Social Identity Theory. The individuals are more empathetic and more helpful because they feel more closeness to the people who are in-group members (Paciello et. al., 2013; Tajfel \& Turner, 1979; Tajfel, 1982).

Helping behavior has two ways: Material or spiritual. According to the studies in literature, spiritual helping is easier than financial helping and they do not have to share any material things such as money when they help spiritually. Research on material helping argues that explaining the purpose of helping increase the amount of financial helping (Diener \& Tay, 2017).

When the studies in the literature are examined, many study findings prove that helping behavior differs depending on social identity of individual who need help and individuals who are empathic or not (Atkins, Hart \& Donnelly, 2004; Canioz \& Coskun, 2019; Paciello et. Al., 2013; Richman, DeWall \& Wolff, 2015; Sierksma, Thijs \& Verkuyten, 2014; Welp \& Brown, 2014). However, there is no study examining how social identity, empathy and helping behavior differ within the same research pattern, depending on Turkish, Syrian and Greek groups, and showing the moderator role of empathy in the impact of social identity on helping behavior. Secondly, Syrian refugees escaped from the war environment to Turkey. It was aimed to examine in detail how this situation had an impact on Turkish citizens' empathy and helping behavior. Thirdly, by including Greeks who are living in another neighboring country and who are not currently in a war environment, the empathy and helping behaviors towards Turkish, Syrian and Greek groups have been examined in detail. For all these purposes, in this study, it is aimed to investigate whether empathy and helping behaviors differ in the case of the individual who is Turkish, Syrian or Greek, and the moderator role of empathy in the effect of social identity on helping behavior. When this research design was examined and discussed, it was benefited from believing in the same religion, norm of responsibility, feeling guilty and Conservation of Resources Theory.

\section{Materials and Methods}

\section{Participants}

The sample group of this study consisted of 184 university students who were continuing their undergraduate education at Bolu Abant Izzet Baysal 
University. The sample included 147 female students and 37 male students. The mean age of students was found to be $\mathrm{X}=21.03(\mathrm{SD}=1.68)$.

\section{Data Collection Tools}

\section{Pre-Manipulation}

To neutralize before manipulation, participants were asked to draw a map of the campus of Bolu Abant Izzet Baysal University and manipulation was made after this application.

\section{Social Identity}

For the purpose of social identity manipulation, short stories prepared by researchers in accordance with three different conditions and applied to participants. The first condition is about a Turkish university student, the second condition is about a Syrian university student and the third condition is about a Greek university student who needs participant's help. In every condition, a photograph of a university student was given and they were asked to write and evaluate the situation of this student for 2 minutes. In addition, a text describing the situation of the university student in need of help was given. Syrian groups have been selected because of their exposure to positive and negative attitudes in Turkey. They are living away from the battlefield environment and society. On the other hand, the Greek group was preferred because they lived in a neighboring country, such as the Syrian group, but are not currently living under similar conditions with Syrian migrants.

\section{Basic Empathy Scale (BES)}

In order to measure empathy in the study, Basic Empathy Scale (BES), which was developed by Jolliffe and Farrington (2006) and adapted to Turkish by Topcu, Erdur-Baker and Capa-Aydın (2016), was used. 9 items of the scale measure cognitive empathy and 11 items measure emotional empathy. The scale consists of 20 items in total and 5 points in Likert type. In this study, Cronbach Alpha reliability coefficient of the scale was found to be .72 .

\section{The Help Text}

The help text was prepared to measure helping behaviors by researchers. After social identity manipulation, participants continue to read a text about the university students who are Turkish, Syrian or Greek. In this text, the status of a university student who had been saving 500 Turkish Liras (TL) for a long time for his brother's need and losing this money was detailed. The rest of the text was asked how much to share with him, even if participants had this amount that is needed. In the help text, 500 Turkish Liras (TL) was asked from 0 to 500 as 11-point Likert type. The amount of money given indicated the individual's helping behavior.

\section{Demographic Information Form}

Participants were provided with a form asking for their personal information such as gender, age, place of birth, education and income. In addition, on the first page of the scale, it was stated that they could voluntarily participate in this study and quit if they wanted.

\section{Process and Statistical Analysis}

Participants were recruited in groups of four to each laboratory and randomly assigned to each experimental condition. In addition, in order to neutralize premanipulation, participants were asked to draw a map of the campus of Bolu Abant Izzet Baysal University and manipulation was made after this application. All participants filled the questionary (Pre-manipulation question, manipulation of social identity, Basic Empathy Scale, the Help Text and Demographic Information Form).

Ethics committee permission was obtained for this research in 3.27.2018 (Protocol number: 2018/92).

The findings were analyzed with the SPSS 21.0 analysis program. One Way Anova and moderator analyses were performed. In addition, the power of the research was found as .92 .

\section{Results}

Examination of Helping Behavior and Empathy Variables According to Social Identity Condition

One-way Anova was used to examine whether helping behavior and empathy variables differ according to conditions of Turkish, Syrian and Greek university students. According to results of analysis, it was seen that helping behavior and empathy scores differ significantly in all three conditions (Table 1).

Table 1. Examining the variables according to social identity condition

\begin{tabular}{|c|c|c|c|c|c|}
\hline Variables & Turkish & Syrian & Greek & $\mathbf{F}$ & $\mathbf{p}$ \\
\hline Helping Behavior & $\begin{array}{l}213.98 \\
(102.45)\end{array}$ & $\begin{array}{l}354.03 \\
(115.69)\end{array}$ & $\begin{array}{l}271.29 \\
(127.30)\end{array}$ & 23.45 & $.00 * *$ \\
\hline Empathy & $\begin{array}{l}73.24 \\
(10.25)\end{array}$ & $\begin{array}{l}78.02 \\
(5.99)\end{array}$ & $\begin{array}{l}62.86 \\
(6.83)\end{array}$ & 57.28 & $.00 * *$ \\
\hline
\end{tabular}

$* \mathrm{p}<.05, * * \mathrm{p}<.01$

When helping behavior was examined, it was seen that the group with the highest amount of helping was the condition of Syrian students $(\mathrm{X}=354.03, \mathrm{SD}=115.69)$ and the least helping group was participants in Turkish student condition ( $\mathrm{X}=213.98, \mathrm{SD}=102.45)$ (Graphic 1). 
Graphic 1. Differentiation of helping behavior according to social identity condition

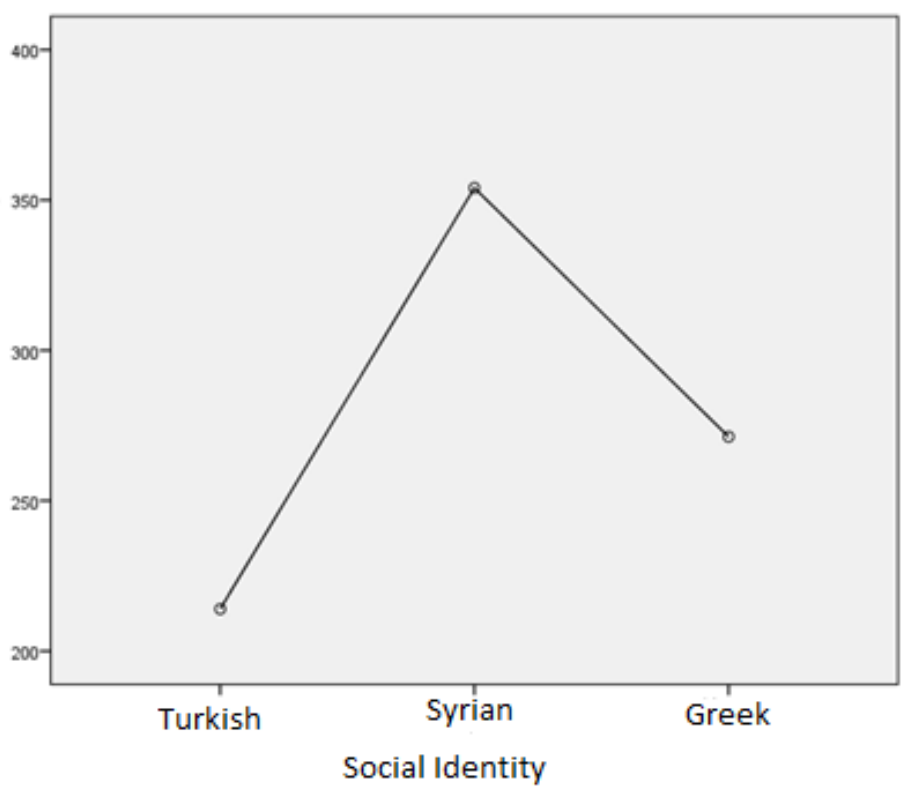

When the empathy variable is examined, it is found that

lowest group is the condition of Greek participants the group with the highest empathy scores is the $(\mathrm{X}=62.86, \mathrm{SD}=6.83)($ Graphic 2$)$. condition of Syrian students $(X=78.02, S D=5.99)$ and the

Graphic 2. Differentiation of empathy scores according to social identity conditions

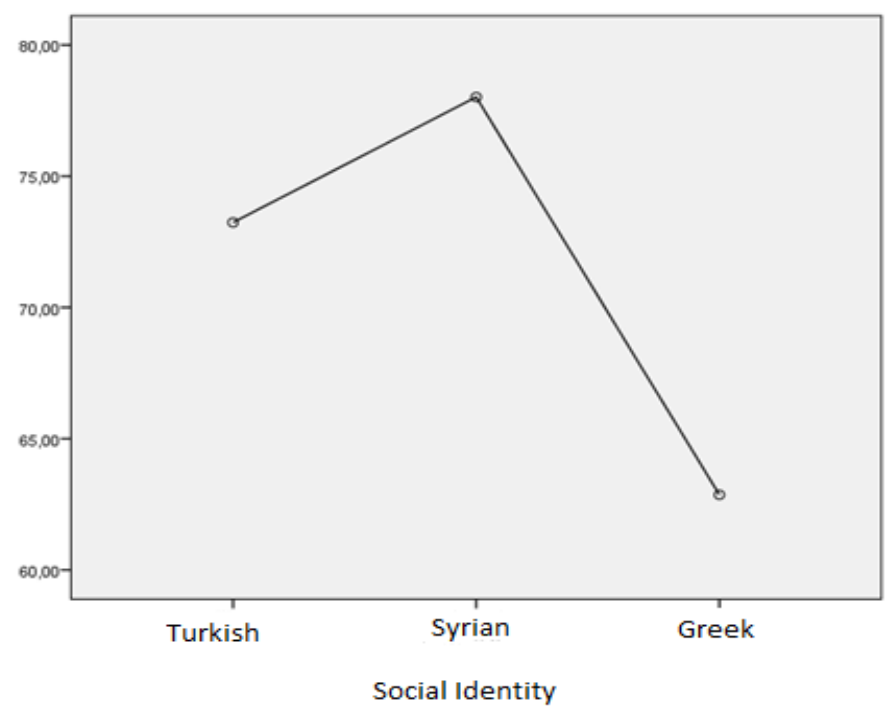

Investigation of the Effect of Social Identity and Empathy on Helping Behavior

Moderator analysis (multiple linear regression) was used to examine the role of empathy in the impact of social identity on helping behavior. When the findings are examined, it is seen that social identity and empathy have a significant common effect on helping behavior. According to this result, empathy has a moderator role in the effect of social identity on helping behavior. 
Table 2. The interaction of social identity and empathy

\begin{tabular}{|c|c|c|c|c|c|c|c|c|}
\hline \multirow[t]{2}{*}{ Model Variables } & \multirow[t]{2}{*}{ b } & \multirow[t]{2}{*}{ SH } & \multirow[t]{2}{*}{$\mathbf{T}$} & \multirow[t]{2}{*}{$\mathbf{p}$} & \multicolumn{2}{|c|}{$\% 95 \mathrm{CI}$} & \multirow[t]{2}{*}{$\Delta \mathbf{R}^{2}$} & \multirow[t]{2}{*}{$\mathbf{R}^{2}$} \\
\hline & & & & & Alt $S$. & Üst $S$. & & \\
\hline $\begin{array}{l}\text { Predictive Variables } \\
\text { (Constant) }\end{array}$ & 331.38 & 173.83 & 1.91 & .05 & -11.63 & 674.38 & & \\
\hline Basic Effects & & & & & & & & \\
\hline Social Identity & -184.00 & 80.33 & -2.29 & .02 & -342.51 & -25.50 & & \\
\hline Empathy & -2.36 & 2.42 & -.97 & .33 & -7.13 & 2.42 & & \\
\hline 2-Way Interactions & & & & & & & & \\
\hline Model $^{\mathrm{a}}$ & 3.48 & 1.18 & 2.96 & .00 & 1.16 & 5.80 & .41 & .18 \\
\hline
\end{tabular}

${ }^{*} p<.05 ; p<.01 ;$ Predicted variable $=$ Helping Behavior

In the slope analysis conducted in order to examine this interaction in depth, the significance of the difference between conditions in the 16th (low level of empathy), 50th (average level of empathy) and 84th (high level of empathy) percentages of the distribution of the regulatory variable was tested (Hayes, 2013: 250). Analysis showed low $(\mathrm{X} \rightarrow \mathrm{Y} /(\mathrm{W}=62)=31.88, \mathrm{SH}=13.46, \mathrm{t}=2.37, \mathrm{p}$
$=.01,95 \% \mathrm{CI}[5.32,58.44]$, mean $(\theta \mathrm{X} \rightarrow \mathrm{Y} /(\mathrm{W}=72)=$ $66.70, \mathrm{SH}=12.87, \mathrm{t}=5.18, \mathrm{p}=.00,95 \%$ CI $[41.29$, 92.11] and high empathy $(\theta \mathrm{X} \rightarrow \mathrm{Y} /(\mathrm{W}=82.40)=$ $102.91, \mathrm{SH}=21.06, \mathrm{t}=4.89, \mathrm{p}=.00,95 \%$ CI $[61.36$, 144.46] differences between the conditions are significant. The graph containing the result is presented below.

$\mathrm{Y}=\mathrm{b}_{0}+\mathrm{b}_{1} \mathrm{~W}_{\text {empathy }}+\mathrm{b}_{2} \mathrm{D}_{\text {identity }}+\mathrm{b}_{3} \mathrm{D}_{\text {identity }} \mathrm{W}_{\text {empathy }}$

Graphic 3. Conditional effects of social identity in low, medium and high level of empathy

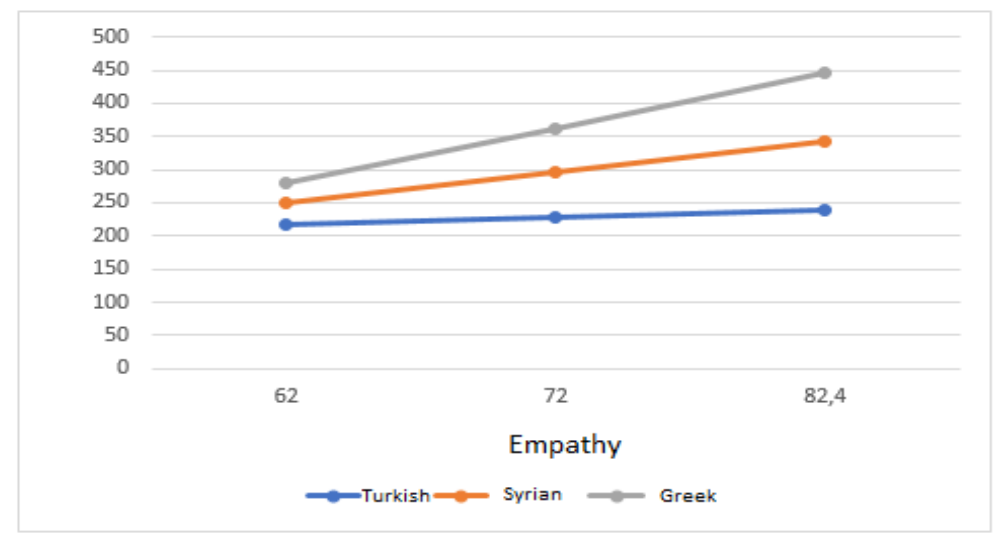

When findings are examined, it is seen that social identity has a significant effect on helping behavior in participants with low, moderate and high level of empathy.

\section{Discussion}

According to findings of this research, it was seen that helping behavior and empathy scores of participants differed significantly according to social identity. In addition, it has been concluded that empathy has a moderator role in the effect of social identity on helping behavior.

When the literature is examined, there are many research findings showing that individuals' helping behaviors differ according to their in-groups and out-groups (Dovidio et. al., 1997; Levine, Cassidy \& Brazier, 2002; Tajfel \& Turner, 1979; Tajfel, 1982). According to findings of this study, it was concluded that participants who are in Syrian student condition helped the most. The reason for this finding is thought to be guilt and have embarrassment. According to the principle of someone who needs help against a community that escaped from war and lived under difficult conditions, both under the influence of these feelings and with the norm of social responsibility. Also, people can choose to help more to someone who believe in the same religion (Tangney et. al., 1996; Oswald and Harvey, 2000). Finally, if the individual will not share anything for real from them, they can also act as a protector for out-group members and help them more than their in-group members accordingly to Conservation of Resources Theory (Yurur, 2011). The findings of this research shows that the participants choose to help Syrian and Greek group university students more than Turkish student.

When findings related to empathy were examined, there were similar results with helping behavior and it was found that empathy scores of participants in Syrian student condition were significantly higher than other conditions. As mentioned above, although there are studies in the literature indicating that the individual is more empathic towards same group members (Johnston \&Glasford, 2017; Levine, Cassidy \& Brazier, 2002; 
Tajfel \& Turner, 1979), findings of this research do not overlap in literature. The reason for these results, as mentioned above, is assumed to be the norm of social responsibility and sense of guilt felt towards individuals who escape from war (Tangney et. al., 1996; Oswald \& Harvey, 2000). People can choose to feel empathy more to someone who believes in the same religion and are living together in this country. Also, Turkey's collectivist society has a culture of both open and why participants like to be helpful even for Syrians are exposed to implicit discrimination more than empathy. For Greek group we can say that Turkish and Greek group do not have any same religion, participants can not have any guilt for them and responsibility and also, Greek group did not escape from any war environment. After these some differenties, participants can feel the least empathy to Greek student (Basil, Ridgway \& Basil, 2006; Oswald \& Harvey, 2000; Zebel, Doosje \& Spears, 2009).

The impact of social identity on helping was examined and empathy was found to have a moderator role in this relationship. When literature information is examined, it is seen that groups of individuals and whether they approach empathically to the individual, is an effect on helping behaviors (Johnston \& Glasford, 2017; Levine, Cassidy \& Brazier, 2002). For example, in a study conducted with children, it is seen that children help people and approach empathically more even if they are members of an out-group (Sierksma, Thijs \& Verkuyten, 2014). In another study to help an out-group member, if an individual feels responsibility and empathic towards that member, helping behavior increases (Zebel, Doosje \& Spears, 2009).

\section{Conclusion}

In this study, the effect of social identity on helping behavior and moderator role of empathy in this effect were examined. This study has an important place in literature since there is not any comparative study of Turkish, Syrian and Greek groups in the literature and there is not any study examining the variables of social identity, empathy and helping behavior in the same pattern. In addition, there is a significant in group difference in terms of helping behavior and empathy.

The big importance of this study is that it touches upon the difficulties experienced by a group that had to migrate from their countries due to the war and try to settle in their new country. Today in Turkey, there are a large number of Syrian refugees. Government and agencies want to help the refugees and the results of this study are intended to shed light on this help. Empathy is also supported by this research finding that approaching empathy is the main factor for helping and the basic requirement for helping a group different from us. Additionally, in order to end the longstanding political disputes between Greece and Turkey, two groups in the environment where empathy to each other thanks to the helping behavior will show after a combined them. For all these purposes, the findings of this research serve as a guide to today's most critical social and political problems.

For future research it is suggested that social identity, empathy and helping behavior should be discussed in detail through newly developed manipulations and repetition of the research by adding new groups. And researchers can repeat this research design with new variables.

\section{References}

Atkins, R., Hart, D. \& Donnelly, T. M. (2004). Moral identity development and school attachment. Moral

development, self, and identity, 65-82.

Basil, D. Z., Ridgway, N. M. \& Basil, M. D. (2006). Guilt appeals: The mediating effect of responsibility. Psychology \& Marketing, 23 (12), 1035-1054.

Canioz , E. K. \& Coskun, H. (2019). The Impact of Social Identity and Empathy on Helping Behavior: The Moderator Role of Empathy, International Journal of Scientific and Technological Research, 5 (12).

Diener, E. \& Seligman, M. E. (2002). Very happy people. Psychological science, 13(1), 81-84.

Diener, E. \& Tay, L. (2017). A scientific review of the remarkable benefits of happiness for successful and healthy living. Happiness, 90.

Dovidio, J. F., Gaertner, S. L., Validzic, A., Matoka, K., Johnson, B. \& Frazier, S. (1997). Extending the benefits of recategorization: Evaluations, self disclosure, and helping. Journal of Experimental Social Psychology, 33(4), 401420 .

Feddes, A. R., Mann, L. \& Doosje, B. (2015). Increasing selfesteem and empathy to prevent violent radicalization: a longitudinal quantitative evaluation of a resilience training focused on adolescents with a dual identity. Journal of Applied Social Psychology, 45(7),400-411.
James, T. K. \& Zagefka, H. (2017). The importance of national identities and intergroup relations in disaster aid. In Intergroup Helping. Springer.

Jolliffe, D. \& Farrington, D. P. (2006). Development and validation of the Basic Empathy Scale. Journal of adolescence, 29(4), 589-611.

Johnston, B. M. \& Glasford, D. E. (2017). Intergroup contact and helping: How quality contact and empathy shape out-group helping. Group Processes \& Intergroup Relations.

Levine, M., Cassidy, C., Brazier, G. \& Reicher, S. (2002). SelfCategorization and By stander Non-intervention: Two Experimental Studies 1. Journal of Applied Social Psychology, 32(7), 1452-1463.

Light, S. N., Moran, Z. D., Swander, L., Le, V., Cage, B., Burghy, C., \& Davidson, R. J.(2015). Electromyographically assessed empathic concern and empathic happinesspredict increased prosocial behavior in adults.Biological psychology, 104, 116-129.

Oarga, C., Stavrova, O. \& Fetchenhauer, D. (2015). When and why is helping others good for well-being? The role of belief in reciprocity and conformity to society's expectations. European Journal of Social Psychology, 45(2), 242-254.

Oswald, D. L. \& Harvey, R. D. (2000). Hostile environments, stereotype threat, and math performance among undergraduate women. Current Psychology,19(4), 338-356. 
Paciello, M., Fida, R., Cerniglia, L., Tramontano, C. \& Cole, E. (2013). High cost helping scenario: The role of empathy, prosocial reasoning and moral disengagement on helping behavior. Personality and Individual Differences, 55(1), 3-7.

Pavey, L., Greitemeyer, T. \& Sparks, P. (2012). "I help because I want to, not because you tell me to" empathy increases autonomously motivated helping. Personality andSocial Psychology Bulletin, 38(5), 681-689.

Richman, S. B., DeWall, C. N. \& Wolff, M. N. (2015). Avoiding affection, avoiding altruism: Why is avoidant attachment related to less helping? Personality and Individual Differences, 76, 193197.

Spinrad, T. L., Eisenberg, N., Cumberland, A., Fabes, R. A., Valiente, C., Shepard, S. A., \& Guthrie, I. K. (2006). Relation of emotion-related regulation to children's socialcompetence:A longitudinalstudy. Emotion, 6(3), 498.

Sierksma, J., Thijs, J. \& Verkuyten, M. (2014). Children's intergroup helping: The role of empathy and peer group norms. Journal of Experimental Child Psychology, 126,369-383.

Stürmer, S., Snyder, M., Kropp, A. \& Siem, B. (2006). Empathymotivated helping: The moderating role of group membership. Personality and Social Psychology Bulletin, 32(7), 943-956.
Tajfel, H. \& Turner, J. C. (1979). An integrative theory of intergroup conflict. The social psychology of intergroup relations, 33(47), 74 .

Tajfel, H. (1982). Social psychology of intergroup relations. Annual review of psychology, 33(1),1-39.

Topçu, Ç., Baker, Ö. E. \& Aydın, Y. Ç. (2016). Temel empati ölçeği Türkçe uyarlaması: geçerlik ve güvenirlik çalışması. Türk Psikolojik Danışma ve Rehberlik Dergisi, 4(34).

Van Leeuwen, E., Van Dijk, W. \& Kaynak, Ü. (2013). Of saints and sinners: How appeals to collective pride and guilt affect outgroup helping. Group Processes \& Intergroup Relations, 16(6), 781-796.

Verkuyten, M. \& Reijerse, A. (2008). Intergroup structure and identity management among ethnic minority and majority groups: The interactive effects of perceived stability, legitimacy, and permeability. European Journal of Social Psychology, 38(1), 106-127.

Welp, L. R. \& Brown, C. M. (2014). Self-compassion, empathy, and helping intentions. The Journal of Positive Psychology, 9(1), 54-65.

Zebel, S., Doosje, B. \& Spears, R. (2009). How perspectivetaking helps and hinders group-based guilt as a function of group identification. Group Processes \& Intergroup Relations, 12(1),61-78 